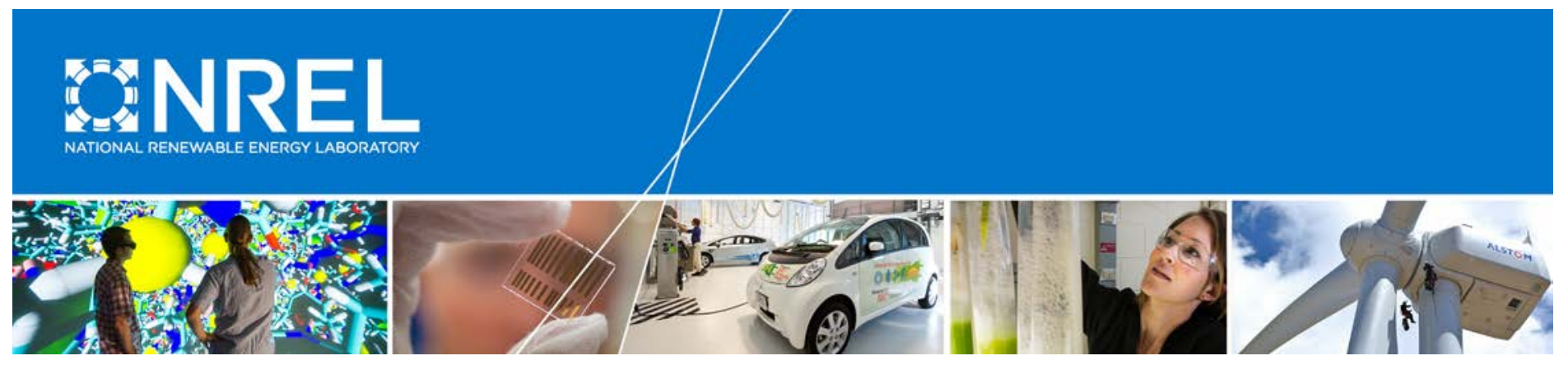

\title{
ERCOT-FESTIV Modeling
}

Cooperative Research and Development Final Report

CRADA Number: CRD-15-584

NREL Technical Contact: Ibrahim Krad

NREL is a national laboratory of the U.S. Department of Energy Office of Energy Efficiency \& Renewable Energy Operated by the Alliance for Sustainable Energy, LLC

This report is available at no cost from the National Renewable Energy Laboratory (NREL) at www.nrel.gov/publications.

CRADA Report

NREL/TP-5D00-65843

February 2016

Contract No. DE-AC36-08GO28308 


\title{
NOTICE
}

This report was prepared as an account of work sponsored by an agency of the United States government. Neither the United States government nor any agency thereof, nor any of their employees, makes any warranty, express or implied, or assumes any legal liability or responsibility for the accuracy, completeness, or usefulness of any information, apparatus, product, or process disclosed, or represents that its use would not infringe privately owned rights. Reference herein to any specific commercial product, process, or service by trade name, trademark, manufacturer, or otherwise does not necessarily constitute or imply its endorsement, recommendation, or favoring by the United States government or any agency thereof. The views and opinions of authors expressed herein do not necessarily state or reflect those of the United States government or any agency thereof.

This report is available at no cost from the National Renewable Energy Laboratory (NREL) at www.nrel.gov/publications.

Available electronically at SciTech Connect http:/www.osti.gov/scitech

Available for a processing fee to U.S. Department of Energy and its contractors, in paper, from:

\author{
U.S. Department of Energy \\ Office of Scientific and Technical Information \\ P.O. Box 62 \\ Oak Ridge, TN 37831-0062 \\ OSTI http://www.osti.gov \\ Phone: 865.576.8401 \\ Fax: 865.576.5728 \\ Email: reports@osti.gov
}

Available for sale to the public, in paper, from:

\author{
U.S. Department of Commerce \\ National Technical Information Service \\ 5301 Shawnee Road \\ Alexandria, VA 22312 \\ NTIS http://www.ntis.gov \\ Phone: 800.553 .6847 or 703.605 .6000 \\ Fax: 703.605.6900 \\ Email: orders@ntis.gov
}




\section{Cooperative Research and Development Final Report}

In accordance with Requirements set forth in Article X: REPORTS AND PUBLICATIONS, A.2 of the CRADA agreement, this document is the final CRADA report, including a list of Subject Inventions, to be forwarded to the Office of Science and Technical Information as part of the commitment to the public to demonstrate results of federally funded research.

Parties to the Agreement: Electric Reliability Council of Texas (ERCOT)

CRADA Number: CRD-15-584

CRADA Title: : ERCOT - FESTIV Modeling

Joint Work Statement Funding Table Showing DOE Commitment:

\begin{tabular}{|c|c|}
\hline Estimated Costs & NREL Shared Resources \\
\hline Year 1 & $\$ 10,760.00$ \\
\hline TOTALS & $\$ 10.760 .00$ \\
\hline
\end{tabular}

\section{Abstract of CRADA Work:}

Ibrahim Krad will travel to ERCOT Austin Headquarters for one month to help develop the ERCOT FESTIV model and train ERCOT staff to operate the model.

\section{Summary of Research Results:}

Ibrahim successfully developed the fully nodal ERCOT model as well as a reduced zonal model for use with the FESTIV tool. Model was demonstrated in front of ERCOT engineers and ERCOT engineers were shown how to use the model themselves.

\section{Subject Inventions Listing:}

None

\section{Report Date:}

$1 / 27 / 16$

Responsible Technical Contact at Alliance/NREL:

Ibrahim Krad

\section{Name and email address of $P O C$ at company:}

Julia Matevosjana

Julia.Matevosjana@ercot.com

7620 Metro Center Drive

Austin, Texas 78744

This document contains NO confidential, protectable, or proprietary information. 